\title{
CHILDREN'S LITERATURE
}

Susan Manly

In a series of notebook entries and manuscript fragments written between 1798 and 1802, Samuel Taylor Coleridge reflected on the words and actions of his sons.

Originally intending to write about 'Infancy \& Infants', he continued to be fascinated by his children as they grew, often associating their perceptions and pleasures with scenes of nature, as in this entry from c. 28 September 1802 :

Children in the wind -- hair floating, tossing, a miniature of the agitated Trees, below which they play'd -- the elder whirling for joy, the one in petticoats, a fat Baby, eddying half willingly, half by the force of the Gust -- driven backward, struggling forward -- both drunk with the pleasure, both shouting their hymn of Joy. ${ }^{1}$

Here the game played by Hartley and Derwent (born in 1796 and 1800 respectively) seems a continuation of the motion of the trees and the wind itself, the younger boy only half impelled by voluntary movement, both children closely allied to and taking active 'Joy' in being part of nature, 'whirling' and 'eddying' in sympathy with the gust. A fragment from a letter written in the same year similarly dwells on the purity and

\footnotetext{
${ }^{1}$ The Notebooks of Samuel Taylor Coleridge, 5 vols, ed. Kathleen Coburn and others (London: Routledge and Kegan Paul, 1957-2002), i. 330 (no. 21.32); see also Collected Letters of Samuel Taylor Coleridge, ed. Earl Leslie Griggs, 6 vols (Oxford: Clarendon
} Press, 1956-71), ii. 872. 
naturalness of children's thinking, as Coleridge recalls asking Hartley, lost in contemplation on a river bank, 'what his Thoughts were': 'he hugged me, \& said after a while "I thought, how I love the sweet Birds, \& the Flowers, \& Derwent, and Thinking; and how I hate Reading, \& being wise, \& being Good". ${ }^{2}$ Earlier, Coleridge comments on Hartley's 'Brahman love \& awe of Life' and resolves 'to commence his Education with natural History'. ${ }^{3}$ For Coleridge, a child's thinking powers were instinctive, a natural energy and motion continuous with that of birds and flowers, to be encouraged to flow freely, not to be forced into artificial channels through the imposition of uncongenial reading. Such an education would constitute an erroneous attempt to mould what was already naturally right. A training in 'being wise, $\&$ being Good' through the medium of moral tales, such as those published by the Anglo-Irish children's writer Maria Edgeworth between 1796 and 1801, is accordingly condemned in an 1805 notebook entry. Edgeworth and others, Coleridge felt, delivered 'detailed Forewarnings' that were harmful to the natural growth of a child's mind, creating 'an impression of Fatality, that extinguishes Hope'. ${ }^{4}$

Yet much of the literature written for younger readers in the late eighteenth and early nineteenth centuries, including Edgeworth's, is informed by a body of educational theory that sought to liberate children from unnatural constraints, and to ensure that their voices were heard and their ways of seeing respected. The two seminal influences were John Locke and Jean-Jacques Rousseau, both of whom had described childhood as a time of relative liberty. In 'Some Thoughts Concerning Education' (1693), Locke had

\footnotetext{
${ }^{2}$ To Sara Hutchinson, [early summer 1802], Collected Letters of Coleridge, ii. 804.

${ }^{3}$ Coleridge, Notebooks i. 959 (no. 4.84).

${ }^{4}$ Coleridge, Notebooks, ii. 2418 (no. 21.583).
} 
advised of children that '[a]1l their innocent Folly, Playing, and Childish Actions are to be left perfectly free and unrestrained', especially open-air play in the sun and wind. ${ }^{5}$ Seventy years later in Emile (1762), Rousseau had similarly urged his readers to '[1]ove childhood, indulge its sports, its pleasures, its delightful instincts', and, anticipating Coleridge's dislike of moral tales as a means of curing 'evil tendencies', remarked: 'What a poor sort of foresight, to make a child wretched in the present with the more or less doubtful hope of making him happy at some future day. ${ }^{, 6}$ Both Locke and Rousseau had laid emphasis on the importance of listening carefully and imaginatively to children, advice that Coleridge clearly took to heart, and that Edgeworth echoed both in her educational theory and in fiction based on her observations of her numerous younger siblings.

On the socializing effects of education, however, opinions were sharply divided. While Locke had emphasized children's rationality and approved of their eagerness to learn the culture of the society in which they found themselves, Rousseau had highlighted the tendency of conventional education to produce a child who was, paradoxically, both 'slave and tyrant, crammed with knowledge but empty of sense', obedient to adult authority, but utterly dependent. Rousseau explicitly rejected Locke's idea of inducting the child into an overtly hierarchical community in which it consciously learned to be an 'obedient Subject' under adult government. ${ }^{7}$

\footnotetext{
5 'Some Thoughts Concerning Education', in The Educational Writings of John Locke, ed. James L. Axtell (Cambridge: Cambridge University Press, 1968), 156, 121.

${ }^{6}$ Jean-Jacques Rousseau, Emile, or Education, trans. Barbara Foxley (London: Dent, 1911), 43.

${ }^{7}$ Locke, 'Some Thoughts', 145.
} 
These contrasting attitudes inform the very different view of children's reading in Locke and Rousseau. Whereas Locke had taken it for granted that a child needs to learn to read as soon as he can talk, preferably by being 'brought to desire to be taught' and by being made to associate reading with 'Honour, Credit, Delight and Recreation', Rousseau was more doubtful about the value of books for children. ${ }^{8}$ He regarded the conventional rote learning of historical dates and of words such as 'king, emperor, war, conquest, law, and revolution' as a 'flood of words [that] overwhelms [a] sad and barren childhood'. In its place, he argued that the child's memory is better employed in trying to make sense of the world for himself: 'everything he sees and hears makes an impression on him, he keeps a record of men's sayings and doings, and his whole environment is the book from which he unconsciously enriches his memory, till his judgment is able to profit by it'. 9

The children's literature that emerged from this long-running debate about how best to preserve or shape 'the child' was intimately connected to the post-Rousseau explosion of interest in educational theory and in the promise represented by childhood. From the mid-eighteenth century on, a vigorous and constantly expanding market for children's books existed, initially focused on London, but gradually extending into the provinces, and into Scottish and Irish metropolitan centres. By the end of the century, the conservative Sarah Trimmer, one of the pioneers of children's literature, expressed disquiet about the sheer number of new books aimed at the rising generation, a 'daily

\footnotetext{
${ }^{8}$ Locke, 'Some Thoughts', 255.

${ }^{9}$ Rousseau, Emile, 75, 76.
} 
supply' produced for their 'gratification' but not necessarily, she thought, for their good. $^{10}$

One of the grounds for her anxiety about this burgeoning publishing industry was the increasing politicization of writing for children. Locke and Rousseau had focused attention on the analogy between the familial order, in which adults exerted power over children, and what could be construed as an unjust social order. In addition, they had analysed the differences between an education that aimed to recognize children's intrinsic equality with adults as human beings and one that treated them as slaves, possessions, or playthings. These enquiries into the purposes and effects of early education had strong resonances in the French revolutionary period, when the revision of children's place in the family order was a significant part of the revolutionary overturning of hereditary authority. Lynn Hunt notes that the revolutionary era saw increasing emphasis on the 'independent sphere of action of children' and an attack on the idea of paternal power, closely associated with the unnatural authority accorded to the French king. ${ }^{11}$ Similarly, Jay Fliegelman argues that late eighteenth-century American debates about the family focused on the move towards 'filial autonomy and the unimpeded emergence from nonage', and entailed broad changes in the understanding of the paternal role, no longer seen as inhering in the use of unlimited, legitimate patriarchal power to extort children's obedience, but as a responsibility to

${ }^{10}$ Sarah Trimmer, The Guardian of Education: A Periodical Work, 5 vols (London: J. Hatchard, 1802-6), i. 15.

${ }^{11}$ Lynn Hunt, The Family Romance of the French Revolution (London: Routledge, 1992), 27, 65. 
prepare children to govern themselves. ${ }^{12}$ Fliegelman traces these shifts in a number of fictional works widely read in late eighteenth-century America.

We can also see these politicized changes in the representation of family hierarchies at work in the books for children produced between 1781 and 1806 by Anna Barbauld, John Aikin, Mary Wollstonecraft, Maria Edgeworth, and William Godwin. In 1784, Immanuel Kant had declared that the 'courage to use your own reason' was the central precept for progress towards an enlightened society and culture, envisaging the result as 'man's emergence from his self-incurred immaturity'. ${ }^{13}$ This was an idea that the five writers named above, on whom I will focus in this chapter, took as a maxim from which children as well as adults could benefit. Wollstonecraft and Godwin were among those who associated this freedom of enquiry and thought with a questioning of established family hierarchy. For them, the traditional patriarchal family was a means of training children in subjection and passive obedience, which not only damaged them as individuals but also hindered the furthering of the public good. Wollstonecraft criticizes the 'absurd duty, too often inculcated, of obeying a parent only on account of his being a parent'; this, she argued, 'shackles the mind, and prepares it for a slavish submission to any power but reason'. ${ }^{14}$ Godwin likewise argues that political justice entails the ability to see and to speak truthfully, hampered by a mistaken 'principle in regal states .

${ }^{12}$ Jay Fliegelman, Prodigals and Pilgrims: The American Revolution Against Patriarchal Authority, 1750-1800 (Cambridge: Cambridge University Press, 1982), 3.

${ }^{13}$ Immanuel Kant, An Answer to the Question: 'What is Enlightenment?', trans. H. B. Nisbet (1970; Harmondsworth: Penguin, 2009), 1.

${ }^{14}$ Mary Wollstonecraft, A Vindication of the Rights of Woman (London: J. Johnson, 1792), 351. 
. to think your father the wisest of men because he is your father, and your king the foremost of his species because he is a king, ${ }^{15}$ The clearest expression of this radical enlightenment critique is in Wollstonecraft's posthumously published Lessons, originally written for her daughter, Fanny Imlay, in 1795, where she schools her child to think of herself as strong and capable, telling her stories about the mistakes 'mamma' and 'papa' made as children to show her that just like her, they were once small and fallible. The fragment ends by reassuring the child that she does already 'know how to think' and to reason from her experience, and by holding out the hope that this is the beginning of her existence as a rational being: 'Another day we will see if you can think about any thing else'. ${ }^{16}$

In the early years of the French Revolution, both French and British radicals made direct connections between the promise held out by children and a new era of political equality. For Joseph Priestley, writing in 1791, a proper education is one that responds to

the new light which is now almost every where bursting out in favour of the civil rights of men ... While so favourable a wind is abroad, let every young mind expand itself, catch the rising gale, and partake of the glorious enthusiasm; the great objects of which are the flourishing state of science, arts, manufactures, and commerce, the extinction of wars, with the calamities incident to mankind from

${ }^{15}$ William Godwin, An Enquiry Concerning Political Justice, 2 vols (London: G. G. J. and J. Robinson, 1793), ii. 427-8.

${ }^{16}$ [Mary Wollstonecraft], Posthumous Works of the Author of A Vindication of the Rights of Woman, 4 vols (London: J. Johnson, 1798), ii. 195-6. 
them, the abolishing of all useless distinctions, which were the offspring of a barbarous age. $^{17}$

Priestley's metaphor of a 'rising gale' stirring a 'glorious enthusiasm' in 'every young mind' anticipates Coleridge's observation of his sons' joy in a windy day, but whereas Coleridge focuses on proximity to nature as a source of pleasure, Priestley links the naturalness of progressive politics to children's enthusiasm for knowledge and enlightenment. Isaac Kramnick takes Priestley's words as a confirmation that late eighteenth-century literature for children was "part of the political assault on aristocratic England', and one of its distinctive features is that it frequently addressed actual social problems and conflicts (the title of Wollstonecraft's novel for adolescent girls, Original Stories from Real Life, is indicative). ${ }^{18}$ The aim of such writings was to make ideas and current debates available to children, sometimes obliquely, sometimes directly, and encourage them to use their imaginations to empathize with others, stimulating independent, open, and compassionate powers of judgement, and enabling child readers to see and think critically and reflectively.

This did not necessarily entail losing sight of what Coleridge called 'a love of "the Great", \& "the Whole", the access to a sublime vision that he associated with early exposure to fairy tales and the fantastic, rather than with the realism of the new

${ }^{17}$ Joseph Priestley, The Proper Objects of Education in the Present State of the World (London: J. Johnson, 1791), 30.

${ }^{18}$ Isaac Kramnick, 'Children's Literature and Bourgeois Ideology', in Pérez Zagorin (ed.), Culture and Politics: From Puritanism to the Enlightenment (Berkeley: University of California Press, 1980), 227. 
children's literature that he despised. ${ }^{19}$ Barbauld's Hymns in Prose (1781), an influential collection of meditations on natural phenomena, presents nature to the child as a kind of book that he or she can learn to read, telling of God's presence and character. In Hymn VI, for instance, Barbauld invokes her reader as a 'child of reason', a child who thinks but who needs to be stirred to more profound perceptions. ${ }^{20}$ The child's vision is initially confined to what is evident to the physical senses: 'I saw the moon rising behind the trees: it was like a lamp of gold . . . Presently I saw black clouds arise, and roll towards the south; the lightning streamed in thick flashes over the sky; the thunder growled ... I felt afraid, for it was loud and terrible'. The adult voice, entering into dialogue with that of the 'child of reason', urges: 'Did thy heart feel no terror, but of the thunderbolt? Was there nothing bright and terrible, but the lightning? Return, O child of reason, for there are greater things than these. -- God was in the storm, and didst thou not perceive him? ${ }^{21}$ Barbauld imagines herself as simultaneously both child and adult in this dialogue; the child who recites the hymn similarly occupies the subject-position of both learner and teacher. We might read this as the child's internalization of adult doctrine and the disciplining of its mind, as Alan Richardson has suggested, but the child is given access through this exchange to the sublime, encouraged to travel imaginatively beyond mere appearance, to 'return' to the world with new eyes. ${ }^{22}$

${ }^{19}$ To Thomas Poole, 16 Oct. 1797, Collected Letters of Coleridge, i. 854.

${ }^{20}$ Anna Barbauld, Hymns in Prose for Children (London: J. Johnson, 1781), 36.

${ }^{21}$ Barbauld, Hymns, 40-1.

${ }^{22}$ Alan Richardson, Literature, Education, and Romanticism: Reading as Social Practice (Cambridge: Cambridge University Press, 1994), 64-77. 
Coleridge might also have been surprised to read a manuscript draft for a children's book completed by Godwin (supposedly an atheist) in 1806, written in the form of a familiar, affectionate letter to a small boy, recounting the events experienced and conversations enjoyed during a walk together in the country. Godwin begins with straightforward descriptions of the rural scenes the two have witnessed -- cows grazing in a field, a village church -- but the piece ends with an extended and rapturous evocation of 'the great invisible principle acting every where, which maintains the life of every thing'. ${ }^{23}$ Godwin communicates a Blakean sense of the equal holiness of all living things, showing the child reader how he arrives at insight through initial error. At first, as a solitary walker in nature, he mistakenly perceives the world as something he alone possesses, 'the sole and undisputed lord of the whole country'. But his second thoughts teach him that he is not alone, and not set above and apart from others: "“every thing about me lives, $\&$ when I observe of them that they like me have life $\&$ health, $\&$ are continually experiencing those changes which are indications of health, I can almost say to the tree $\&$ the shrub, Thou art my brother!", 24

The insight into the fraternity of all of creation that Godwin makes available both to his fictional and his projected child reader recalls Barbauld's emphasis in Hymns in Prose on God's tender care for all of his 'family' on earth. God is not a threatening patriarch in Barbauld's Hymns, but a nurturing, maternal presence. In contrast with Isaac Watts's Divine Songs (1715), the best-selling collection of hymns for children to which Hymns in Prose is a response, Barbauld never threatens her child reader with divine punishment: in Hymns III and VIII, it is kings, not children, who are warned of

\footnotetext{
${ }^{23}$ Oxford, Bodleian Library, MS Abinger.c.24, fol. 26r.

${ }^{24}$ MS Abinger.c.24, fols.28r, 28v.
} 
retribution for their injustice. Watts's 'All-seeing God' has a 'piercing Eye' that sees the 'secret Actions' of the child and keeps a written record of 'every Fault'; Barbauld's God likewise has an 'eye that never sleepeth', but only because he is continually watching over and caring for his children as they sleep. ${ }^{25}$ Barbauld portrays the divine parent in Hymn V as arranging everything for the comfort of his family: 'As the mother moveth about the house with her finger on her lips, and stilleth every little noise, that her infant be not disturbed; as she draweth the curtains around the bed, and shutteth out the light from its tender eyes; so God draweth the curtains of darkness around us; so he maketh all things to be hushed and still, that his large family may rest in peace. ${ }^{26}$

William Blake similarly repudiates Watts's punitive vision of an authoritarian God in his Songs of Innocence and of Experience (1789/1793). In one of the many poems in this collection that satirize and criticize Watts, Blake's lullaby, 'A Cradle Song', reimagines Barbauld's evocation of God's maternal nurturance, and rejects Watts's earlier focus on 'burning flame, | Bitter groans and endless crying'. Watts's 'A Cradle Hymn', the poem that Blake is targeting, presents troubled and angry reflections on the 'cursed sinners' who failed to recognize the Christ-child as a 'lovely babe' whose face was 'Spotless fair, divinely bright!' Instead of deriving comfort and joy from the sight of her own infant, the mother in Watts's poem is disturbed by the 'affront' offered by human sinners to their 'King', which 'makes me angry while I sing'. She hopes that her child will look on God's face after death, if he learns to praise him, but Watts's mother dwells on the distance between her human infant and the divine 'blessed

\footnotetext{
${ }^{25}$ Isaac Watts, Divine Songs, ed. J. H. P. Pafford (London: Oxford University Press, 1971), 'Song IX: The All-Seeing God', lines 1, 3, 24; Barbauld, Hymns, 30.

${ }^{26}$ Barbauld, Hymns, 32-3.
} 
babe'. ${ }^{27}$ In contrast, Blake's 'Cradle Song' focuses on the congruence between the tranquil happiness of a sleeping baby and the 'happy silent moony beams' that tell of God's love. For the mother speaker of his poem, her baby mirrors the 'holy image', transmitting God's smiles through his own natural closeness to the divine: 'Thou his image ever see, | Heavenly face that smiles on thee'. Through her contemplation of her child, the mother learns that God smiles 'on thee, on me, on all', that 'Infant smiles are his own smiles', and that God thus 'Heaven \& earth to peace beguiles'. ${ }^{28}$ Even the ambiguous verb 'beguiles' is significant, shedding any uneasy associations with guile or sinful cunning to suggest something closer to 'reconciles': the human baby, effortlessly and uncomplicatedly mediating Christ, eradicates the distance between the human and the divine. Subversively, Blake displaces the powerful mother of Barbauld's Hymn V in favour of an apparently powerless infant. Similarly, in 'The Little Black Boy' he quietly dismisses Watts's 'pity [for] those that dwell | Where ignorance and darkness reign', and Barbauld's more humane but still condescending evocation of an enslaved 'negro woman' weeping over her child in Hymn VII: the black boy is the enlightened evangelist here, the communicator of God's 'beams of love' to the white child. ${ }^{29}$

Frequently, the child characters in the children's books written by radicals and reformists are invited to see themselves as capable of achieving great things, whether in the exercise of artistic prowess, philanthropic action, or moral virtue. Maria

${ }^{27}$ Watts, 'A Cradle Hymn', lines 46-7, 19, 22, 37, 18, 24, 30, 32, 17. This poem was added to the eighth edition of Divine Songs in 1727.

${ }^{28}$ Blake, 'A Cradle Song', lines 4, 22, 27-8, 29, 31, 32.

${ }^{29}$ Watts, 'Song V: Praise for Birth and Education in a Christian Land', lines 13-14; Barbauld, Hymns, 60; Blake, 'The Little Black Boy', line 14. 
Edgeworth's stories are distinguished by their markedly secular tone and focus on real social situations -- 'imitations of real life' (Preface) -- in place of the natural supernaturalism of Barbauld's Hymns and the politicized spirituality of Blake's Songs. Yet many of her tales echo Barbauld's and Blake's liberating emphasis on children's agency. 'Waste Not, Want Not', for example, a short story published in 1800 in the third edition of Edgeworth's tales for children, The Parent's Assistant, emphasizes the inventive capacities of children, and connects this problem-solving potential with social good, suggesting children's transformative role as citizens of the future. Their capacity to address economic injustice and create a more unified society is imagined as emerging from secular innovations, from the growth of knowledge and 'abolition of useless distinctions' identified by Joseph Priestley -- not from religious conviction. Edgeworth uses her narrative of two contrasting boys to interrogate the conspicuous excess of aristocratic presumption and to show the value of reciprocal social bonds. Both concepts are symbolized by the two boys' treatment of a piece of whipcord used to bind a parcel at the outset of the story: one of the boys, ambitious to be a member of an élite group of rich children, discards the string as worthless; the other, less conformist boy preserves the whipcord out of respect for its potential usefulness, and his valuation of the humble binding is vindicated. It proves crucial to his eventual triumph in the archery competition which closes the tale, and Edgeworth shows that his attentiveness to the importance of ordinary, workaday objects is the foundation for his conscientious commitment to the just distribution of wealth, and his rejection of the 'useless distinctions' which Priestley saw as 'producing an absurd haughtiness in some, and a base servility in others' ${ }^{30}$ In other stories by Edgeworth, such as 'The Orphans', 'Lazy

${ }^{30}$ Priestley, The Proper Objects of Education in the Present State of the World, 30. 
Lawrence', and 'Simple Susan', the child heroes and heroines overcome economic disadvantage and social marginalization through their resilience and determination, their capacity to learn new skills and invent solutions to their problems, their curiosity and willingness to think for themselves, and their independence, to a greater or lesser extent, from adult assistance. Strikingly, many of these heroes or heroines have missing or inadequate parents, pioneering the trope of the brave and resourceful lone child so important in later children's fiction.

As Edgeworth does in 'Waste Not, Want Not', John Aikin invites his readers to review their understanding of 'greatness' and of conformity in several stories from Evenings at Home, the six-volume work co-written with his sister, Anna Barbauld, between 1792 and 1796. In 'The Cost of a War', a dialogue between a child and his father, Aikin takes up Priestley's idea that early education should assist children to form enquiries that will lead to the extinction of war and its associated calamities. The father tells his son that he wants to give him 'some idea of the cost of a war to the people among whom it is carried on', in order to warn Oswald, and the child reader of the tale, against 'the admiration with which historians are too apt to inspire us for great warriors and conquerors'. Taking the example of the Rhineland campaign of Louis XIV and his ministers and generals, the father shows Oswald the immorality of obedience to unjust authority ('Right and wrong are no considerations to a military man. He is only to do as he is bid'), and describes the destruction that is the consequence of this uncritical obedience. He ends the dialogue by inviting Oswald to join him in his disapproval of conquerors ('pest[s] of the human race') and of soldiering as 'a profession which binds a man to be the servile instrument of cruelty and injustice', and therefore not 'an 
honourable calling, ${ }^{31}$ The point is reiterated in 'Great Men', in which Mr C-- and his son Arthur discuss what constitutes true greatness. Mr C-- argues that 'the external advantages of rank and power' can be mistaken for heroism, but signal only 'greatness of station' rather than 'greatness of character'; and recommends James Brindley, the consulting engineer for the construction of the Bridgewater canal, as someone who, though a 'mere countryman' has triumphed through 'the force of his own genius' ${ }^{32}$

The extent to which the ideas in Aikin's writing for children engaged with the political preoccupations of the early 1790 s becomes clearer when we examine biographical evidence. In her Memoir of John Aikin (1823), Lucy Aikin quotes from a letter of 1792 or 1793, when the Evenings at Home stories and dialogues were being written, in which her father refers to "the horrible events that are now going on in the political world', attributing their causes to 'the accursed spirit of military despotism', and expressing his 'resentment against tyranny' and his attachment to 'liberty and mankind' ${ }^{33}$ A subsequent letter to a friend, enclosing the third volume of Evenings at Home, protests against the viciously punitive sentences on charges of sedition of the Scottish democrats, Thomas Muir and Thomas Palmer, in August and September 1793. Aikin cites their confinement in the hulks as 'an example of tyranny scarcely, I think, legal, certainly not decent', and implies that he is among those 'enemies to the present

${ }^{31}$ [John Aikin and Anna Barbauld], Evenings at Home; or the Juvenile Budget Opened 6 vols (London: J. Johnson, 1792-6), v. 55, 58, 63.

${ }^{32}$ Evenings at Home, vi. 13, 16, 10, 11.

${ }^{33}$ Lucy Aikin, Memoir of John Aikin, M.D., 2 vols (London: Baldwin, Cradock, and Joy, 1823), 156. 
system' who felt 'much emotion' at the outcome of the trials. ${ }^{34}$ Increasingly, Aikin acknowledged that government restrictions on freedom of speech and the fact that Britain was at war with revolutionary France made it difficult to publish controversial views that might lead to accusations of 'rejoic[ing] in the calamities of our country', although he privately expressed his loathing of this 'bloody, expensive, and I think, unjust war' in another letter of 1793. It was impossible to speak or write openly of dissent from government policy, for fear of being accused of 'maintaining French principles', Aikin complained; 'the state of public opinion in this country' was thus endangered, turning the British public into 'persecutors and slaves. If persons of reading and reflection are hurried along with this torrent of false opinion, what is left on which to found a hope of saving us from the lowest degradation? ${ }^{35}$

What was left was the hope that might be placed in a new generation of readers, thinkers, and enquirers. Lucy Aikin comments that faced with Evenings at Home, 'an intelligent reader of mature age' would discern 'notices of [Aikin's] opinions on many highly important topics', presumably including his politics. ${ }^{36}$ Although younger readers might not have been able to identify the nature of the political ideas expressed, the fact that Aikin chose to use the dialogue form for pieces critical of unjust wars and of established notions of 'honour' and 'greatness' suggests the modelling of debate and enquiry that he wanted to survive the era of Pitt's Terror. Lucy Aikin comments that this promotion of discussion was an important element of the Aikin children's own upbringing: the narrative forms used in Evenings at Home were a reflection of 'his

\footnotetext{
${ }^{34}$ Aikin, Memoir, 161.

35 Aikin, Memoir, 159-61.

${ }^{36}$ Aikin, Memoir, 157.
} 
manner of living and conversing with his children in the bosom of their home' ${ }^{37}$ She later recounts how valuable Aikin considered his children's comments when working on his General Biography, a series of lives of great men and women: he 'invited and encouraged the freest strictures even from the youngest and most unskilful of those whom he was pleased to call his household critics', enjoying their discussion of each article, 'carried on under the indulgent guidance of one who did not desire even from his own children a blind and prejudiced adherence to his opinions', ${ }^{38}$

This ideal of enquiry and discussion was also central to Godwin's Juvenile Library project, a children's literature publishing house which he launched in 1805 and which quickly rose to be one of the most successful of the children's booksellers in London. Other Juvenile Libraries pre-existed Godwin's, including that of John Harris, who had inherited the thriving business of the children's publishing pioneer, John Newbery. Like these other firms, Godwin published fables, Bible stories, histories, nursery rhymes, and moral tales, written by a range of authors, Charles and Mary Lamb among them. Godwin himself wrote an impressive range of books for children under various pseudonyms, the most common of which was 'Edward Baldwin'. He had prepared for his new venture by reading many of the children's books published by his close friend, the liberal publisher Joseph Johnson, whose list included Wollstonecraft, Edgeworth, Barbauld, and Aikin, and who had employed Blake as the illustrator for a number of works, including Wollstonecraft's Original Stories and her translation of Christian Salzmann's Elements of Morality.

\footnotetext{
${ }^{37}$ Aikin, Memoir, 157.

${ }^{38}$ Aikin, Memoir, 200, 201.
} 
Cannily, Godwin echoed the titles of other bestselling children's authors: he published a Parent's Offering to rival Edgeworth's Parent's Assistant, and his biography of the illustrator William Mulready, The Looking-Glass: A True History of the Early Years of an Artist, consciously echoes the title Newbery chose for his selection of tales by Arnaud Berquin, a popular French writer for children, published as The Looking-Glass for the Mind, or Intellectual Mirror, with numerous reprints from 1787 on. Berquin's tales are grim, the sort of moral tales that Coleridge thought extinguished hope with their too detailed 'forewarnings'. Perhaps this is why one child reader changed Newbery's subtitle in her copy of Berquin's tales to register her opinion of the book as an 'inelegant collection of the most disagreeable silly stories and uninteresting tales with twenty-four ugly cuts'. ${ }^{39}$ The 'Looking-Glass' genre has a long history, traditionally focusing on great men and offering tales of instruction by example. Godwin instead makes his 'Looking-Glass' a biography of Mulready, a boy from a working-class family who taught himself to draw, illustrated with reproductions of Mulready's early sketches to show readers how he improved over time. Godwin's text encourages ambition, telling its child readers: 'You are informed here of what has actually been done, of what was done, for a long time under every disadvantage of a humble situation'. The artist 'was a child like others, but he was a child of merit. Merit, my young friend, is within your reach too' ${ }^{40}$ Godwin's conception of the child and of what reading is for, visible in this early example of his writing for children, is not

${ }^{39}$ M. O. Grenby, The Child Reader 1700-1840 (Cambridge: Cambridge University Press, 2011), 272.

${ }^{40}$ Theophilus Marcliffe [Godwin], The Looking Glass: A True History of the Early Years of an Artist (London: Thomas Hodgkins at the Juvenile Library, 1805), viii, ix. 
modelled on the preservation of 'naturalness' so important to Coleridge. As Julie Carlson comments, Godwin believed that children's books constituted a means of 'alter[ing] the preconditions of the future by re-forming the child', functioning as 'spaces of rational possibility that should be as free from censorship and illusory notions of freedom as possible'. ${ }^{41}$ Accordingly, Godwin is honest about Mulready's errors and failings and about the difficulties he faced. For the Anti-Jacobin Review (as yet unaware of the true identity of 'Theophilus Marcliffe', the ostensible author of The Looking-Glass), this realistic portrayal compromised the moral lesson that the exemplary life traditionally communicated, but Godwin's frankness was of a piece with his determination to tell his story with 'all the plainness of truth' ${ }^{42}$

Another of Godwin's earliest Juvenile Library productions, Fables, Ancient and Modern (1805), similarly challenges rival collections, eschewing the lengthy morals common in eighteenth-century books of fables such as Samuel Croxall's frequently reprinted Fables of Aesop. To communicate with children, Godwin declares, 'we must become in part children ourselves', introducing 'quick, unexpected turns' into the narration to retain the child's interest, adopting an informal conversational style, and conjuring up pictures 'visible to the fancy of the learner'. Godwin's fables are gentle, the traditional stories reworked to 'end in a happy and forgiving tone' in order to encourage the compassion and kindness 'which a kind and benevolent father would wish to cultivate in his child'. He avoids abstract moralizing, since he wants to '[form] the mind of the learner to habits of meditation and reflection' rather than thinking for

\footnotetext{
${ }^{41}$ Julie Carlson, England's First Family of Writers (Baltimore: Johns Hopkins University Press, 2007), 213, 217.

${ }^{42}$ Anti-Jacobin Review 25.102 (Dec. 1806), 424; Marcliffe, The Looking Glass, viii.
} 
his reader. ${ }^{43}$ Sarah Trimmer's reaction to this statement of intent is telling: Godwin's Fables were 'destitute ... of moral, and every thing that should characterize a Fable Book, ${ }^{44}$

The philosophy behind Godwin's children's books was painstakingly thought through in his 1797 work, The Enquirer. Here, Godwin repeatedly, almost obsessively, returns to the question of children's freedom, contrasting an education founded on the 'tyranny of implicit obedience' with a schooling that preserves liberty of mind. ${ }^{45} \mathrm{He}$ therefore urges a radical review of the balance of power between adult authority and the child-subject, a plan 'calculated entirely to change the face of education ... Strictly speaking, no such characters are left upon the scene as either preceptor or pupil. The boy, like the man, studies, because he desires it . . Everything bespeaks independence and equality'. ${ }^{46}$ The young reader's mind should gain the 'habits of intellectual activity', learning 'to think, to discriminate, to remember, and to enquire'. ${ }^{47}$ Uncensored reading and the avoidance of prescriptive moralizing was therefore important.

Godwin's The Pantheon: or Ancient History of the Gods of Greece and Rome . . . For the Use of Schools, and Young Persons of Both Sexes (1806), one of his most commercially successful books, underlines his determination to supersede outmoded approaches to children's reading, and to foster their powers of mind and ability to

\footnotetext{
${ }^{43}$ Edward Baldwin [Godwin], Fables, Ancient and Modern (London: Thomas Hodgkins at the Juvenile Library, 1805), iv, ii.

${ }^{44}$ Trimmer, Guardian of Education, v. 296.

${ }^{45}$ Godwin, The Enquirer (London: G. G. and J. Robinson, 1797), 60.

${ }^{46}$ Godwin, Enquirer, 80.

${ }^{47}$ Godwin, Enquirer, 5-6.
} 
enquire. This was among the works that met with strong disapproval from the government spy who informed against the Juvenile Library in 1813. In his report, the spy alleged that The Pantheon was 'insidious and dangerous' and 'calculated to mislead', improperly promoting 'heathen morality' and an appetite for the 'grossest stories' in Greek and Roman mythology. ${ }^{48}$ Godwin's dedication had explicitly set his new mythology against the 'elaborate calumny' upon the Greek religion in conventional literature for children. ${ }^{49}$ By showing children the beauty, imaginative power, and idealism of the stories about the gods, Godwin's stated aim was to 'conciliate the favour of young persons to the fictions of the Greeks' ${ }^{50}$ He rejects his rivals' dismissal of the Greek religious imagination as superstitious and idolatrous, instead praising its capacity as a system of ideas to 'awaken the imagination; imagination, which, it cannot be too often repeated, is the great engine of morality'. ${ }^{51}$ In Chapter 2, 'Genius of the Grecian Religion', Godwin discourses on the tendency for the ancient Greeks to give 'animation and life to all existence'. ${ }^{52}$ This animating impulse, Godwin intimates, is deeply implanted in the human mind, not only in ancient Greece but in modern England, since

\footnotetext{
${ }^{48}$ Domestic, Geo. III., 1813. January to March. No. 217, Public Record Office, quoted in Pamela Clemit, 'Philosophical Anarchism in the Schoolroom: William Godwin's Juvenile Library, 1805-22', Biblion: The Bulletin of the New York Public Library, 9.1/2 (Fall 2000/ Spring 2001), 44-70 (45).

${ }^{49}$ Edward Baldwin [Godwin], The Pantheon: or Ancient History of the Gods of Greece and Rome, $2^{\text {nd }}$ edn (London: M. J. Godwin at the Juvenile Library, 1809), v.

${ }^{50}$ Baldwin, Pantheon, vi.

${ }^{51}$ Baldwin, Pantheon, viii.

${ }^{52}$ Baldwin, Pantheon, 5.
} 
as imaginative and social beings we delight 'to talk to the objects around us, and to feel as if they understood and sympathised with us: we create, by the power of fancy, a human form and a human voice in those scenes, which to a man of literal understanding appear dead and senseless'. ${ }^{53}$ Godwin accounts for religious feeling, the peopling of the world with gods of the human mind, by thinking about human psychological needs: 'we love, as Pope says, to "see God in clouds, and hear him in the wind". 54 This love of stories and visions is for Godwin a profoundly embedded and powerful impulse in humans, often associated dismissively with childhood, but in reality a life-long characteristic, and one that impels thought through its capacity to arouse strong feeling.

The kind of imagination that these Romantic writers sought to nurture in children was one fully engaged with real events and real passions. They produced books in which stories prompted thought and fancy, but at the same time wanted to introduce children to the adult world of political reality, because, like Locke and Rousseau, they regarded children as beings 'of the same nature with ourselves; born to have passions and thoughts and sentiments of [their] own; born to fill a station, and act a part' ${ }^{55}$ For most of the writers I have discussed, opposition to the restriction of what children might read or think, feel, or imagine, was deeply rooted in their political convictions and their sense of the means by which progress might be achieved. Dissent and disagreement, the encouragement of free enquiry and speculation, were essential elements of their conception of an improved social order.

\footnotetext{
${ }^{53}$ Baldwin, Pantheon, 5-6.

${ }^{54}$ Baldwin, Pantheon, 5.

${ }^{55}$ Godwin, Enquirer, 142.
} 
Wordsworth retains this idea of the promise symbolized by childhood in the 1799 version of The Prelude, a work which responds passionately to the 'fructifying virtue' of what is experienced and felt in early life. For Wordsworth, childhood was associated with an intensity of hope -- a bosom 'beat[ing] with expectation' and with 'desire | Resistless'. Wordsworth's adult understanding and his poetic energy are illuminated by his child-self's 'obscure sense | Of possible sublimity', that teaches him that there is yet 'something to pursue', 'meanings of delight' still legible in ' $[\mathrm{t}] \mathrm{he}$ surface of the universal earth'. This is vital to the 'growth of mental power', especially the 'imaginative power', in which he locates his hope for the future beyond the disasters of the revolutionary years. But childhood was also reconstructed by him as a time of unthinking, visceral pleasure, when, 'A naked savage in the thunder-shower', he enjoyed the 'grandeur in the beatings of the heart', without needing to understand it. ${ }^{56}$ Like the 'boy of Winander' who is taught only by 'old Grandame Earth', Wordsworth's remembered childhood is decisively set apart from the world of books, and is essentially a natural education, not a social one ${ }^{57}$ Coleridge's ecstatic conclusion to 'Frost at Midnight' similarly locates his baby's education in 'far other scenes' in which the child will hear the 'sounds intelligible' of an 'eternal language' in 'lakes and shores | And mountain crags' ${ }^{58}$ These visions of a 'natural' childhood emerge out of moments of

${ }^{56}$ William Wordsworth, The Prelude: 1799, 1805, 1850, ed. Jonathan Wordsworth, M. H. Abrams, and Stephen Gill (New York: Norton, 1979), 1799 version, Book 1, lines 290, 41-3; Book 2, lines 366-7, 371; Book 1, lines 197-9, 257, 293, 26, 141.

${ }^{57}$ Wordsworth, Prelude, 1805 version, Book 5, line 346. See lines 290-449 for Wordsworth's contrast of the infant 'prodigy' with the boy of Winander. ${ }^{58}$ Coleridge, 'Frost at Midnight', lines 56, 64-65, 62-3 (1798 version). 
introspection and retrospection, and tend towards what Alan Richardson calls 'a sort of primitivism, which closes off the prospect for intellectual development' ${ }^{59}$ Yet, while distinct from the socially engaged imagination that the new realists of children's literature sought to nurture in their readers, the Wordsworthian or Coleridgean idealized 'natural' imagination was nonetheless an educative force and potentially an engine of change. As Godwin had argued, 'The human imagination is capable of representing to itself a virtuous community, a little heaven on earth. The human understanding is capable of developing the bright idea, and constructing a model of it' ${ }^{60}$ To foster these capabilities, whether by writing educational works for children or by recollecting and interpreting the visionary energies of childhood, was a shared preoccupation of Romantic writers and part of the broader transformational dynamic of Romanticism.

\footnotetext{
${ }^{59}$ Richardson, Literature, Education, and Romanticism, 106.

${ }^{60}$ Godwin, Thoughts Occasioned by the Perusal of Dr. Parr's Spital Sermon (London: G. G. \& J. Robinson, 1801), 80-1.
} 


\section{FURTHER READING}

Anderson, Robert. 'Godwin Disguised: Politics in the Juvenile Library', in Godwinian Moments: From the Enlightenment to Romanticism, ed. Robert M. Maniquis and Victoria Myers (Toronto: University of Toronto Press, 2011).

Carlson, Julie A. England's First Family of Writers: Mary Wollstonecraft, William Godwin, Mary Shelley (Baltimore: The Johns Hopkins University Press, 2007).

Clemit, Pamela. 'Philosophical Anarchism in the Schoolroom: William Godwin's Juvenile Library, 1805-22', Biblion: The Bulletin of the New York Public Library, 9.1/2 (Fall 2000/ Spring 2001), 44-70.

Grenby, Matthew, The Child Reader 1700-1840 (Cambridge: Cambridge University Press, 2011).

Grenby, Matthew. “"Very Naughty Doctrines”: Children, Children's Literature, Politics and the French Revolution Crisis', in The French Revolution and the British Novel in the Romantic Period, ed. A. D. Cousins, Dani Napton, and Stephanie Russo (New York: Peter Lang, 2011).

McGavran, James Holt (ed.). Romanticism and Children's Literature in NineteenthCentury England (Athens, GA: University of Georgia Press, 1991). 
Manly, Susan. “"Take a 'poon, pig”: Property, Class, and Common Culture in Maria Edgeworth's “Simple Susan”, Children's Literature Association Quarterly, 37.2 (2012), 306-22.

Myers, Mitzi. 'Reading Children and Homeopathic Romanticism: Paradigm Lost, Revisionary Gleam, or "Plus Ça Change, Plus C'est La Même Chose"”, in Literature and the Child: Romantic Continuations, Postmodern Contestations, ed. James Holt McGavran (Iowa City: University of Iowa Press, 1999).

O'Malley, Andrew. The Making of the Modern Child: Children's Literature and Childhood in the Late Eighteenth Century (New York: Routledge, 2003).

Paul, Lissa. The Children's Book Business: Lessons from the Long Eighteenth Century (New York: Routledge, 2011).

Plotz, Judith. Romanticism and the Vocation of Childhood (New York: Palgrave Macmillan, 2001).

Richardson, Alan. Literature, Education, and Romanticism: Reading as Social Practice (Cambridge: Cambridge University Press, 1994).

Rowland, Ann Wierda. Romanticism and Childhood: The Infantilization of British Literary Culture (Cambridge: Cambridge University Press, 2012). 
Ruwe, Donelle, Culturing the Child, 1690-1914 (Lanham, Maryland/Toronto/Oxford: The Children's Literature Association and The Scarecrow Press, 2005).

Trumpener, Katie. 'The Making of Child Readers' in The Cambridge History of English Romantic Literature, ed. James Chandler (Cambridge: Cambridge University Press, 2009). 